\title{
Genetic diversity of the fish pathogen Aeromonas salmonicida demonstrated by random amplified polymorphic DNA and pulsed-field gel electrophoresis analyses
}

\author{
Bronagh O'hIci ${ }^{1}$, Gilles Olivier ${ }^{2}$, Richard Powell ${ }^{1, *}$ \\ 'Department of Microbiology, National University of Ireland, Galway, Ireland \\ ${ }^{2}$ Department of Fisheries and Oceans, Gulf Fisheries Centre, PO Box 5030, Moncton, New Brunswick E1C 9K1, Canada
}

\begin{abstract}
The current taxonomy of Aeromonas salmonicida includes 4 subspecies. A. salmonicida subsp. salmonicida is associated with salmonid fur unculosis, and $A$. salmonicida subsp. achromogenes, A. salmonicida subsp. masoucida, and $A$. salmonicida subsp. smithia are strains that show variation in some biochemical properties. This classification does not readily encompass isolates from a wide range of fish hosts currently described as atypical A. salmonicida. This study examined 17 typical strains, 39 atypical strains and 3 type $A$. salmonicida subspecies strains for genetic similarity using the random amplified polymorphic DNA (RAPD) and pulsed-field gel electrophoresis (PFGE) techniques. On the basis of RAPD- and PFGE-derived profiles, similarity matrices and dendrograms were constructed. The results showed that species $A$. salmonicida constituted a genetically heterogeneous group of strains, encompassing within an homogeneous or clonal lineage comprised solely of typical strains and the $A$. salmonicida subsp. salmonicida type strain.
\end{abstract}

KEY WORDS: Aeromonas salmonicida Fish pathogens $\cdot$ Taxonomy $\cdot$ RAPD $\cdot$ PFGE

\section{INTRODUCTION}

Aeromonas salmonicida is the bacterial agent associated with furunculosis, a disease generally confined to salmonid fish species (Popoff 1984). The organism is readily recovered from the kidney or surface lesions of diseased fish and is conventionally identified by the occurrence of dark brown pigmented colonies on tryptone soya agar after incubation at 20 to $25^{\circ} \mathrm{C}$ for 2 to $4 \mathrm{~d}$. The traditional description of members of this species is: non-motile, fermentative, Gram-negative rods which do not grow at $37^{\circ} \mathrm{C}$ and which produce catalase and oxidase (Popoff 1984). The current taxonomy of A. salmonicida includes 4 subspecies; $A$. salmonicida subsp. salmonicida is associated with salmonid furunculosis and has been arbitrarily termed typical to distinguish this taxon from all other forms of $A$. salmonicida (Austin \& Austin 1993). A. salmonicida subsp.

•Corresponding author. E-mail: richard powell@nuigalway.ie achromogenes (Smith 1963), A. salmonicida subsp. masoucida (Kimura 1969) and A. salmonicida subsp. smithia (Austin et al. 1989) represent aberrant strains that show variation in some biochemical properties.

This classification scheme is complicated by 2 observations. First, repeated isolations of Aeromonas salmonicida subsp. masoucida and subsp. smithia have not been reported since their initial description (Wiklund \& Dalsgaard 1998). Second, there have been many reports describing isolations of A. salmonicida from chronic ulcerative diseases found in both salmonid (Evelyn 1971, Paterson et al. 1980) and nonsalmonid species including carp (Bootsma et al. 1977), minnow (Hastein et al. 1978), goldfish (Elliot \& Shotts 1980, Whittington et al. 1987), Atlantic cod (Cornick et al. 1994), eel (Kitao et al. 1985), sand-eels (Dalsgaard \& Paulsen 1986), pike (Wiklund 1990), flounder (Wiklund \& Bylund 1991, 1993) and turbot (Pedersen et al. 1994). These isolates are termed atypical $A$. salmonicida and differ in various phenetic traits including colony morphology, growth intensity and temperature range, a 
requirement for salt ( $1 \% \mathrm{w} / \mathrm{v}$ sodium chloride), fermentation of carbohydrates, amino acid decarboxylation, and oxidase reaction (Austin \& Austin 1993, Wiklund \& Dalsgaard 1998). Clinical disease signs are often characterized by cutaneous ulceration in comparison to the general septicaemia of typical salmonid furunculosis. The significance of this atypical group of A. salmonicida isolates and their expanded host-range with respect to the health of both feral and cultured fish stocks is unclear. However, infections by atypical strains are a cause of increasing economic concern in aquaculture (Austin \& Austin 1993), and epizootic infections of wild fish stocks have also been reported (Wiklund et al. 1994). Finally, their position in terms of the current taxonomy of $A$. salmonicida is unresolved.

Characterization of genomes is a useful method for both taxonomic and epizootiological studies of bacterial pathogens, and has been applied to Aeromonas salmonicida. DNA:DNA reassociation analysis (Belland \& Trust 1988), plasmid profiling (Nielsen et al. 1993), ribotyping (Nielsen et al. 1994), DNA probes (Gustafson et al. 1992, Hiney et al. 1992), restriction endonuclease analysis (McCormick et al. 1990), random amplified polymorphic DNA analysis (Hanninen et al. 1995, Miyata et al. 1995), and pulsed-field gel electrophoresis (PFGE) (Umelo \& Trust 1998) have concentrated on $A$. salmonicida subsp. salmonicida, revealing this group to be an extremely homogeneous taxon. Only the DNA:DNA reassociation (Belland \& Trust 1988) and PFGE (Umelo \& Trust 1998) analyses included atypical strains (15 and 16 strains respectively), and these reports concluded that the atypical strains are genetically diverse when compared to typical strains.

Here we report a genotypic analysis of 39 strains of atypical Aeromonas salmonicida in comparison with 17 typical strains and the type strains for 3 A. salmonicida subspecies (subsp. smithia was unavailable). Initially, all strains were examined by screening with a putative A. salmonicida species-specific oligodeoxynucleotide DNA probe. Subsequently, the strain collection along with the type $A$. salmonicida strains were analyzed using the random amplified polymorphic DNA (Berget al. 1994) and PFGE (Schwartz \& Cantor 1984) techniques. Finally, the genetic similarities between both the typical and atypical strains and the diversity encompassed by species $A$. salmonicida were evaluated.

\section{MATERIALS AND METHODS}

Aeromonas salmonicida strains. Aeromonas salmonicida type strains were obtained from the National Collection of Industrial and Marine Bacteria (NCIMB), Aberdeen, Scotland, and the strain designations are listed in Table 1. Typical and atypical A. salmonicida strains were collected and the strain designations along with host data and location of isolation (where known) are also listed in Table 1. All typical strains were cultivated in tryptone soya medium (Oxoid, Hampshire, UK) at $22^{\circ} \mathrm{C}$ for $2 \mathrm{~d}$. All atypical strains were cultivated on either nutrient agar (Oxoid), or columbia base (Oxoid) supplemented with $7 \%$ human blood, and incubated at $22^{\circ} \mathrm{C}$ for between 2 and $5 \mathrm{~d}$.

Genomic DNA extraction. Cells were harvested from $10 \mathrm{ml}$ cultures by centrifugation, $8500 \times \mathrm{g}$ for 10 min (Centrifuge 5416, Eppendorf, Hamburg, Germany), and genomic DNA extraction was performed using a modification of a previously described method (Ausubel et al. 1992). Briefly, the bacterial pellets were resuspended and washed in $1 \mathrm{ml}$ of sterile $\mathrm{H}_{2} \mathrm{O}$, followed by centrifugation for $5 \mathrm{~min}$ at $9650 \times g$ (MSE Micro Centaur, Sanyo, UK) and resuspension in $400 \mu \mathrm{l}$ TE buffer (10 mM Tris-HCI, 1 mM EDTA, pH 8.0). The cells were lysed by the addition of $200 \mu$ l of lysozyme (10 $\mathrm{mg} \mathrm{m}^{-1}$ ) (Boehringer Mannheim GmbH, Germany) and incubation at $37^{\circ} \mathrm{C}$ for $60 \mathrm{~min}$. The preparation was then incubated for $10 \mathrm{~min}$ with $40 \mu \mathrm{l}$ of Proteinase $\mathrm{K}\left(10 \mathrm{mg} \mathrm{m}^{-1}\right.$ ) (Boehringer Mannheim) at room temperature, followed by the addition of sodium dodecyl sulphate (SDS) to a final concentration of $1.0 \%$ and incubation at room temperature until the preparation was clear. For the atypical strains, the preparation was further incubated at $60^{\circ} \mathrm{C}$ for 5 min to ensure complete lysis. Eighty $\mu$ l of $0.5 \mathrm{M}$ EDTA were added, mixed by gentle agitation and the solution was deproteinised by sequential phenol and chloroform-isoamyl alcohol $(24: 1 \mathrm{v} / \mathrm{v})$ extraction. The genomic DNA was precipitated in ethanol and resuspended in TE buffer. The DNA concentration was estimated by visual comparison with standard DNA size markers after electrophoresis through a $1 \%$ agarose (BioGene Ltd, Cambridge, UK) TAE gel stained with $0.5 \mu \mathrm{g} \mathrm{m} \mathrm{m}^{-1}$ ethidium bromide (Sigma Chemical Co., St Louis, MO, USA).

$16 S$ rRNA gene analysis. The PCR primer designations, sequences, and reference positions on alignments of $16 \mathrm{~S}$ rRNA sequences are $E B, 5$ GAGTITGATCCTGGCTCAG-3', (bases 3-25) and UN, 5'-ACGGNWACCTTGTTACGAGTT-3' (bases 1423-1402) (standard IUPAC nomenclature: $N$ is $G, A$, $T_{\text {, or }} C_{i} W$ is $A$ or $T$ ). Both PCR primers have been described as specific for most bacterial species (Lane 1991). The $50 \mu$ l reaction contained $10 \times \mathrm{KCl}$ buffer (Biotaq. Bioline Ltc, $\mathrm{UK}$ ) including $1.5 \mathrm{mM} \mathrm{MgCl}_{2}$, $200 \mu \mathrm{M}$ dNTPs (Pharmacia, Uppsala, Sweden), 1 U Taq DNA polymerase (Biotaq, Bioline Ltd), 170 pmol of primer EB, 157 pmol of primer UN and $20 \mathrm{ng}$ of genomic DNA, overlayed with $30 \mu$ l of mineral oil. Negative controls containing no target DNA were included. The reactions were then amplified using a 
TRIO-thermoblock thermocycler (Biometra GmbH, Göttingen, Germany) through 30 cycles of $1 \mathrm{~min}$ at $94^{\circ} \mathrm{C}$, $1 \mathrm{~min}$ at $52^{\circ} \mathrm{C}$ and $1 \mathrm{~min}$ at $72^{\circ} \mathrm{C}$ followed by a final extension of $5 \mathrm{~min}$ at $72^{\circ} \mathrm{C}$, and then held at $15^{\circ} \mathrm{C}$. Five $\mu \mathrm{l}$ aliquots of the amplification products were analyzed by electrophoresis through 1\% agarose (BioGene) TAE gels stained with $0.5 \mu \mathrm{g} \mathrm{m}^{-1}$ ethidium bromide (Sigma). Slot blot hybridization analysis using the Aeromonas salmonicida specific oligodeoxynucleotide (bases 469-486 of A. salmonicida subsp. salmonicida $16 \mathrm{~S}$ rRNA gene) was performed by end labelling $100 \mathrm{ng}$ of the DNA probe, 5'-GGCGCCTAATACGTGTCA-3', with $50 \mu \mathrm{Ci}(\gamma-32 \mathrm{P})$ ATP (DuPont NEN, Hitchin, UK) and 1 U T4 polynucleotide kinase (Promega, Madison, WI, USA). 16S rRNA gene PCR products were denatured by addition of a half volume of $1 \mathrm{M} \mathrm{NaOH}$ and incubation at $55^{\circ} \mathrm{C}$ for $5 \mathrm{~min}$ followed by neutralization by addition of an equal volume of $1 \mathrm{M} \mathrm{HCl}$ prior to application onto a nylon membrane (Nytran, Schleicher \& Schuell, Dassel, Germany) with a 96-well slot blot apparatus (Schleicher \& Schull). Standard hybridization (6x SSC, $1 \times$ Denhardt's solution, $0.1 \%$ SDS) was performed for $8 \mathrm{~h}$ at $51^{\circ} \mathrm{C}$. The filter was then washed twice in $2 \times \mathrm{SSC}$ for $15 \mathrm{~min}$ at room temperature, $1 \times \mathrm{SSC}$ for $15 \mathrm{~min}$ at room temperature, and finally $0.1 \times \mathrm{SSC}$ for $15 \mathrm{~min}$ at $40^{\circ} \mathrm{C}$ before autoradiography.

Random amplified polymorphic DNA (RAPD). The 3 previously described RAPD primers (Caetano-Anolles et al. 1991) used in the study were $\mathrm{H} 1,5^{\prime}$ TGCCGAGCTG- $3^{\prime}$; H2, 5' -AGTCAGCCAC-3'; and H3, 5'-CGCGCCGG-3'. Amplification was performed using a hot bonnet thermocycler (Omnigene TR3 CM220, Hybaid Ltd, Middlesex, UK) with no overlay of mineral oil. The $50 \mu$ reaction contained $10 \times \mathrm{NH}_{4}$ buffer (Bioline Ltd), $4.0 \mathrm{mM} \mathrm{MgCl}_{2}, 200 \mu \mathrm{M}$ of dNTPs (Pharmacia), 2 U Taq DNA Polymerase (Bioline Ltd), 60 to $80 \mathrm{pmol}$ of primer and $20 \mathrm{ng}$ of genomic DNA. Negative control reaction mixtures lacking DNA template were also included. Amplification conditions were
Table 1. Strains of Aeromonas salmonicida examined in this study. In paren-

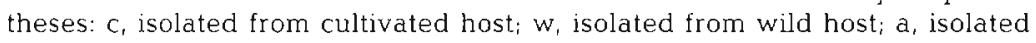
from host in aquarium; $u$, host status unknown; $A$, growth on non-supplemented media; $B$, growth on supplemented media only
Type strains
NCIMB 1102
NCIMB 1110
NCIMB 2020
A. salmonicida subsp. salmonicida
A. salmonicida subsp. achromogenes
A. salmonicida subsp. masoucida

Typical strains

Isolate Source

SRT480 Atlantic salmon Salmo salar, Ireland (c)

0299/M Atlantic salmon Salmo salar, Ireland (w)

BMB2 Atlantic salmon Salmo salar, Scotland (c)

BMA1 Atlantic salmon Salmo salar, Scotland (c)

MT1014 Brown trout Salmo trutta, Norway (u)

$129 / 91$ Salmonid (species unknown), Norway (u)

028 Brown trout Salmo trutta, USA (u)

80204 Atlantic salmon Salmo salar, New Brunswick, Canada (c)

SS70.1 Coho salmon Oncorhynchus kitsutch, USA (u)

95063 Atlantic salmon Salmo salar, Nova Scotia, Canada (c)

BC-7 Atlantic salmon Salmo salar, British Columbia, Canada (c)

1018 Atlantic salmon Salmo salar, Quebec, Canada (c)

65-R Salmonid (species unknown), France (u)

$810 \quad$ Atlantic salmon Salmo salar, Quebec, Canada (c)

BJ Atlantic salmon Salmo salar, New Brunswick, Canada (c)

NS4 Atlantic salmon Salmo salar, Nova Scotia, Canada (c)

A450 Brown trout Salmo trutta, France (u)

\section{Atypical strains}

Isolate Source

M-1 Masou salmon Oncorhynchus masou, Japan (u, A)

86-316 Ling cod Ophiodon elongatus, British Columbia, Canada (w, A)

F661-2/89 Atlantic salmon, Salmo salar, Norway (c, A)

81377 Atlantic cod Gadus morhua, Canada (w, A)

87048 Atlantic salmon, Salmo salar, New Brunswick, Canada (w, A)

F1542-2 Atlantic salmon Salmo salar, Norway (u, A)

K3 Brook trout Salvelinus fontinalis, Newfoundland, Canada (w, A)

88301 Tom cod Gadus microgadus, New Brunswick, Canada (w, A)

94504 Tom cod Gadus microgadus, New Brunswick, Canada (w, A)

94326-2 Tom cod Gadus microgadus, New Brunswick, Canada (w, A)

94326-4 Tom cod Gadus microgadus, New Brunswick, Canada (w, A)

94326-5 Tom cod Gadus microgadus, New Brunswick, Canada (w, A)

Fin3

$143 / 70$

MT373

MT194

MT675

88165

NFD'95 Arctic charr Salvelinus alpinus, Newfoundland, Canada (c, B)

87089 Atlantic salmon Salmo salar, New Brunswick, Canada (c, B)

86663 Atlantic salmon Salmo salar. New Brunswick, Canada (c, B)

87480-an Atlantic salmon Salmo salar, Nova Scotia, Canada (w, B)

87445-1 Atlantic salmon Salmo salar, Canada (C, B)

87445-2 Atlantic salmon Salmo salar, Canada (c, B)

87445 Atlantic salmon Salmo salar, Nova Scotia, Canada

94450 Atlantic salmon Salmo salar, Nova Scotia, Canada

91518 Eel Anguilla anguilla, Nova Scotia, Canada (w, B)

91549 Eel Anguilla anguilla, Nova Scotia, Canada (w, B)

1618.92 Eel Anguilla anguilla, New Brunswick, Canada (w, B)

Fin5 Brown trout Salmo trutta, Finland $(u, B)$

FP9 Unknown host, England (u, B)

Fin6 Brown trout Salmo trutta, Finland $(u, B)$

Fin7 Brown trout Salmo trutta, Finland (u, B)

Fin8 Brown trout Salmo trutta, Finland (u, B)

Fin9 Brook trout Salvelinus fontinalis, Finland $(u, B)$

3.111 Goldfish Carassisus auratus, USA (a, B)

82-83 Goldfish Carassisus auratus, Germany (a, B)

v234/81 Carp Cyprinus carpio, Netherlands (u, B)

T5 Flounder Platichthys flesus, Finland (w, B) 
35 cycles of $10 \mathrm{~s}$ at $94^{\circ} \mathrm{C}, 30 \mathrm{~s}$ at $37^{\circ} \mathrm{C}, 60 \mathrm{~s}$ at $72^{\circ} \mathrm{C}$ and a final extension of $5 \mathrm{~min}$ at $72^{\circ} \mathrm{C}$. Five $\mu \mathrm{l}$ aliquots of the amplification products were analyzed by electrophoresis through 1\% agarose (BioGene), 1\% NuSieve (FMC Bioproducts, Rockland, ME, USA) TAE gels stained with $0.5 \mu \mathrm{g} \mathrm{ml}^{-1}$ ethidium bromide and visualized over UV using the Bio-Profil imaging system (Vilber Lourmat, Marne La Vallee, France). The $100 \mathrm{bp}$ DNA ladder (Life Technologies, Gibco BRL, Renfrewshire, UK) standard length DNA markers were included in each electrophoresis.

Pulsed field gel electrophoreses (PFGE). Colonies of each strain were diluted in sterile $\mathrm{H}_{2} \mathrm{O}$ until an optical density (OD) at $600 \mathrm{~nm}$ of approximately 0.1 was reached. Genomic DNA was prepared in chromosomal grade ultra-pure DNA agarose (Bio-Rad Laboratories, Richmond, USA) as previously described (Cameron et al. 1994). Digestion with restriction enzymes was performed by cutting a slice from \& DNA-containing agarose plug and incubating for $1 \mathrm{~h}$ in the relevant restriction enzyme reaction buffer followed by $4 \mathrm{~h}$ with $20 \mathrm{U}$ of restriction enzyme. Spel enzyme and reaction buffer were obtained from New England Biolabs (Hertfordshire, UK) and Xbal enzyme and reaction buffer were obtained from Promega. The DNA fragments were then subjected to electrophoresis in a $1 \%$ SeaKem agarose (FMC BioProducts) gel submerged in $0.5 \times$ Tris-borate-EDTA buffer using a modified contour clamped homogenous electric field (Pulsaphor Plus, Pharmacia). The running conditions were $12 \mathrm{~V} \mathrm{~cm}^{-1}$ at $14^{\circ} \mathrm{C}$ for $22 \mathrm{~h}$. The pulse times were increased by stepping as follows: $2 \mathrm{~s}$ for $5 \mathrm{~h}, 5 \mathrm{~s}$ for $6 \mathrm{~h}, 9 \mathrm{~s}$ for $6 \mathrm{~h}$, and $12 \mathrm{~s}$ for $5 \mathrm{~h}$ for $\mathrm{Xbal}$ digestions; and $5 \mathrm{~s}$ for $3 \mathrm{~h}, 9 \mathrm{~s}$ for $5 \mathrm{~h}, 12 \mathrm{~s}$ for $5 \mathrm{~h}, 20 \mathrm{~s}$ for $4 \mathrm{~h}, 25 \mathrm{~s}$ for $3 \mathrm{~h}$ and $30 \mathrm{~s}$ for $2 \mathrm{~h}$ for Spel digestions. The concatenated lambda DNA ladder (Pharmacia) was included in each electrophoresis. After electrophoresis, gels were stained in $2 \mu \mathrm{g}$ $\mathrm{ml}^{-1}$ ethidum bromide for $15 \mathrm{~min}$, destained in distilled $\mathrm{H}_{2} \mathrm{O}$ for $15 \mathrm{~min}$, and visualized over UV using the BioProfil imaging system (Vilber Lourmat).

RAPD and PFGE cluster analysis. The molecular lengths of the RAPD- and PFGE-generated DNA fragments were determined using the Bio-Gene software package (Vilber Lourmat) on the Bio-Profil imaging system. Each strain was then visually coded for the presence (coded 1) or absence (coded 0) of each DNA fragment. The data obtained for all 3 RAPD primers were combined into 1 data matrix which was then analyzed using the inverse of Jaccard's similarity coefficient as previously described (Morgan et al. 1993). A similar analysis was performed on the PFGE profiles generated by both SpeI and Xbal restriction enzymes. The similarity dendrograms were generated using the UPGMA clustering method of the PHYLIP phylogeny inference package (Felsenstein 1993).

\section{RESULTS}

\section{S rRNA gene analysis}

Initially, to confirm that all the atypical strains were members of the species Aeromonas salmonicida, their 16S rRNA encoding genes were amplified by PCR and the amplification products were screened with an oligodeoxynucleotide DNA probe designed to specifically target the species $A$. salmonicida. Nucleotide sequences have been described for the 16S rRNA genes of A. salmonicida subsp. salmonicida (GenBank accession number X71836), subsp. achromogenes (X60407), subsp. masoucida (X74680), subsp. smithia (AJ009859) along with the related aeromonad species, A. hydrophila (X74677), A. sobria (X74683), A. media (X74679), and Haemophilus piscium (AJ009860) (Martinez-Murcia et al. 1992, Thornton et al. 1999). A DNA sequence alignment was performed using these sequences and an 18 base oligodeoxynucleotide DNA probe was designed complementary to bases 469 to 486 of the A. salmonicida subsp. salmonicida 16S rRNA sequence. Under the appropriate hybridization conditions, this DNA probe will only recognise the $16 \mathrm{~S}$ rDNA sequences of the 4 accredited $A$. salmonicida

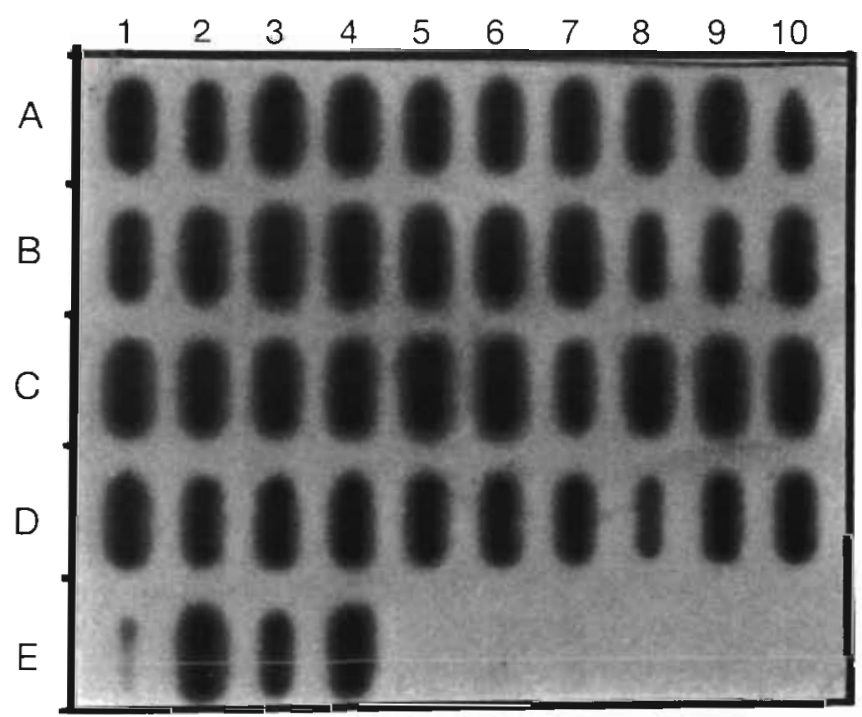

Fig. 1. Aeromonas salmonicida specific $16 \mathrm{~S}$ rDNA slot blot hybridization. Row A: $1, M-1 ; 2,86-316 ; 3, F 661-2 / 89 ; 4$, $81377 ; 5,87048 ; 6, F 1542-2 ; 7, K 3 ; 8,88301 ; 9,94504 ; 10$, 94326-2. Row B: $1,94326-4 ; 2,94326-5 ; 3$, Fin3; 4, 143/70; 5 , MT373; 6, MT194; 7, MT675; 8, 88165; 9, NFD'95; 10, 87089 Row C: 1,$86663 ; 2,87480-$ an $_{i} 3,87445-1 ; 4,87445-2 ; 5,87445$; 6,$94450 ; 7,91518 ; 8,91549 ; 9,1618.92 ; 10$. Fin5. Row D: 1 , FP9; 2, Fin6; 3, Fin7; 4, Fin8; 5, Fin9; 7, 3.111; 8, 82-83; 9, V234/81; 10. T5. Row E: 1, A. sobria; 2, NCIMB 1102; 3, NCIMB 1110; 4, NCIMB 2020; 5, A. media; 6. A. hydrophila; $7, E$. coli. Note: Row D, 6 represents 1 atypical strain that was later removed from this study due to subsequent bacterial contamination of stocks 
subspecies and $H$, piscium and should not react with other aeromonads. Fig. 1 shows that the 16S rDNA amplification products from the atypical $A$. salmonicida strains (Fig. 1, Rows A, B, C \& D) along with the type strains $A$. salmonicida subsp. salmonicida, $A$. salmonicida subsp. achromogenes, and A. salmonicida subsp. masoucida (Fig. 1, Row E, Columns 2, 3 \& 4 respectively), were recognised by this DNA probe. Other species such as A. media, A. hydrophila and $E$. coli showed no hybridization (Fig. 1., Row E, Columns 5,6 \& 7 respectively), and $A$. sobria revealed only a low-intensity hybridization signal (Fig. 1, Row E, Column 1). Bases $469-486$ of the $16 \mathrm{~S}$ rDNA of $A$. sobria are the most similar in sequence homology to the respective region of the $A$. salmonicida $16 \mathrm{~S}$ rDNA with only 2 variant bases. All the atypical $A$. salmonicida strains analyzed in this study reacted with this $A$. salmonicida species-specific DNA probe providing evidence for their membership of this species.

\section{RAPD analysis}

Using the RAPD conditions described, the 3 RAPD primers reproducibly amplified 100 DNA fragments that could be scored for similarity between the Aeromonas salmonicida strains. Fig. 2 shows the RAPD DNA profiles produced for the typical $A$. salmonicida strains using RAPD primer H1 (Fig 2A), RAPD primer $\mathrm{H} 2$ (Fig. 2B) and RAPD primer H3 (Fig. 2C). None of the 3 type $A$. salmonicida subspecies strains showed a pattern identical to one of the other strains with any of the 3 RAPD primers (Fig. 2, lanes 2, 3\& 4 in gels A, B, $\&$ C) although almost all the RAPD fragments amplified from $A$. salmonicida subsp. masoucida NCIMB 2020 (Fig. 2, lane 4) were contained within the RAPD profile of $A$. salmonicida subsp. salmonicida NCIMB 1102 (Fig. 2, lane 2). The RAPD profiles amplified from the typical $A$. salmonicida strains were clearly similar to one another with both the $\mathrm{H} 1$ and $\mathrm{H} 2$ primers, while differences between some typical strains could be noted with the $\mathrm{H} 3$ primer (Fig. 2, lanes 5 to 21 in gels A, B, \& C). The RAPD profiles of these typical strains produced by primers $\mathrm{H} 1$ and $\mathrm{H} 2$ were very similar to those amplified from the type $A$. salmonicida subsp. salmonicida strain (Fig. 2A, lane 2; and Fig. 2B, lane 2).

Fig. 3 shows the RAPD DNA profiles produced for many of the atypical Aeromonas salmonicida strains using RAPD primer $\mathrm{H} 1$ (Fig. 3A), RAPD primer $\mathrm{H} 2$ (Fig. 3B) and RAPD primer H3 (Fig. 3C). It was readily apparent that, regardless of the RAPD primer used, none of the atypical strains produced a RAPD DNA profile similar to any of the type $A$. salmonicida subspecies strains (Fig. 3, lanes 2, 3\& 4 in gels A, B, \& C). Also, when the results of all 3 RAPD primers were combined, no 2 atypical strains produced an identical RAPD DNA profile to each other, although similar RAPD DNA profiles among some atypical strains could be seen with individual RAPD primers (Fig. 3A, lanes 9 \& 10 or lanes $13 \& 14 ; 3 \mathrm{~B}$, lanes $7 \& 8$, lanes $15 \& 16$, or lanes 17 to $21 ; 3 \mathrm{C}$, lanes $19 \& 20$ ). While primer $\mathrm{H} 2$ resulted in the greatest number of common DNA fragments between various atypical strains, primer $\mathrm{H} 3$ produced individual DNA patterns with each strain with few common DNA fragments.

The lengths of the DNA fragments generated by the RAPD primers were determined and the combined RAPD profiles of the typical, atypical and type strains were resolved into numerical matrices and subsequent dendrograms describing genetic similarity. Fig. 4 shows the RAPD-based similarity dendrogram prepared for the typical Aeromonas salmonicida strains.

$\begin{array}{lllllllllll}1 & 2 & 3 & 4 & 5 & 6 & 7 & 8 & 9 & 1011 & 12131415161718192021\end{array}$

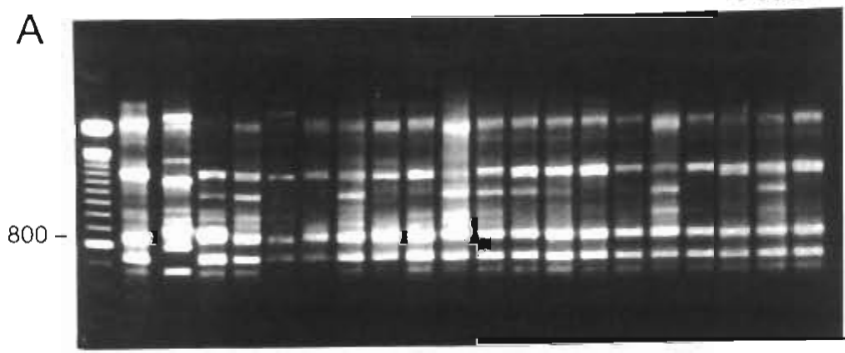

$122 \quad 3 \quad 4 \quad 5 \quad 6 \quad 7 \quad 8 \quad 9101112131415161718192021$

B

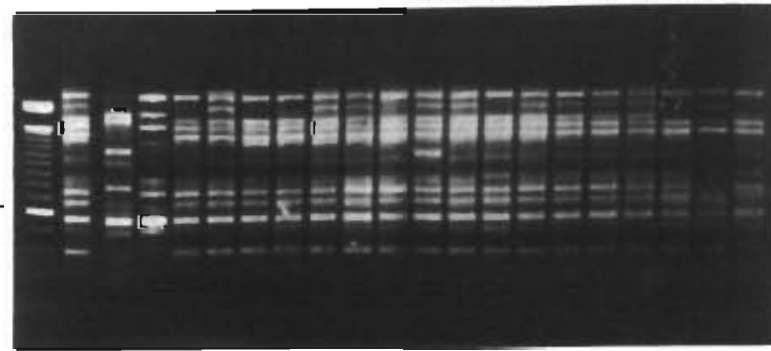

C

$1253 \quad 4 \quad 5 \quad 6 \quad 7 \quad 8 \quad 9101112131415161718192021$

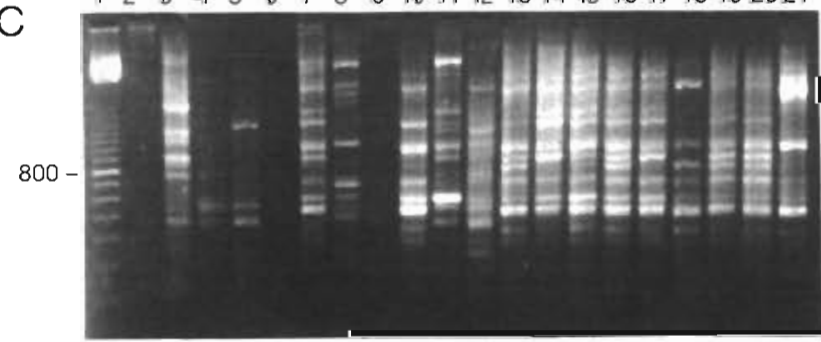

Fig. 2. RAPD profiles of typical Aeromonas salmonicida strains. (A) RAPD primer $\mathrm{H} 1$; (B) RAPD primer $\mathrm{H} 2$; (C) RAPD Primer H3. Lanes: 1, 100 bp DNA molecular size markers (800 bp marker noted on the left); 2 , NCIMB $1102 ; 3$. NCIMB $1110 ; 4$, NCIMB 2020; 5, 0229/M; 6, SRT480; 7, MT1014; $8,129 / 91 ; 9$, BMB2; 10, BMA $1 ; 11,028 ; 12, \mathrm{BC}-7 ; 13,1018$; $14, \mathrm{BJ} ; 15, \mathrm{SS} 70.1 ; 16$, NS4; 17, 80204; 18, 95063; 19, 65-R; 20,$810 ; 21, \mathrm{~A} 450$ 


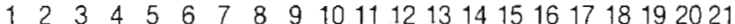

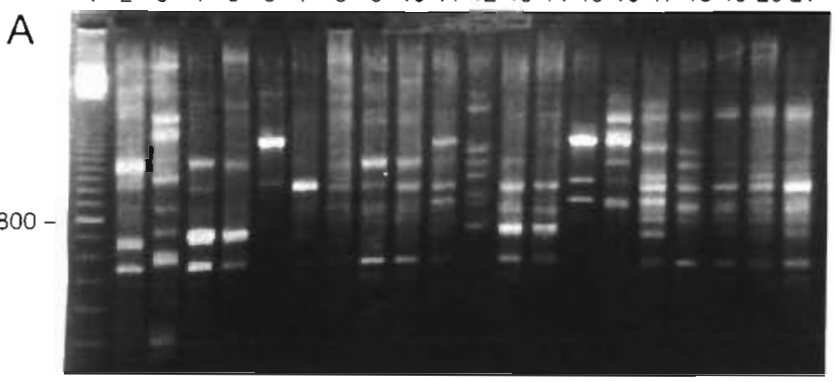

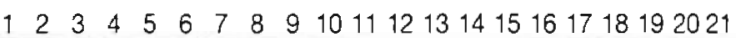
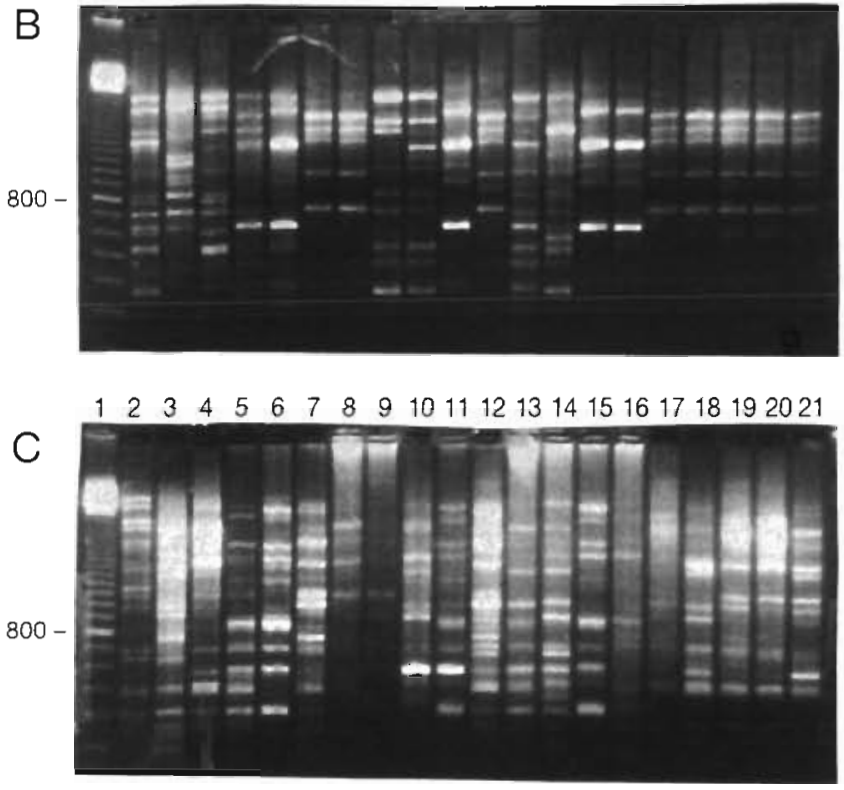

Fig. 3. RAPD protiles of atypical Aeromonas salmonicida strains. (A) RAPD primer $\mathrm{H}_{1}$; (B) RAPD primer $\mathrm{H} 2$; (C) RAPD Primer H3. Lanes: 1,100 bp DNA molecular size markers $(800$ bp marker noted on the left); 2, NCIMB 1102; 3, NCIMB 1110 ; 4, NCIMB 2020; 5, M-1; 6, 86-316; 7, F661-2/89; 8, 81377; 9 , 87048 ; 10, F1542-2; 11, K3; 12, 88301; 13, 94504; 14, 94326-2; $15,94326-4 ; 16,94326-5 ; 17$, Fin3; 18, 143/70; 19, MT373; 20, MT194; 21, MT675

The most distantly related strain was the type $A$. salmonicida subsp. achromogenes strain (NCIMB 1110), which showed less than $70 \%$ RAPD-based similarity to all other typical and type strains. The remaining strains were separated into 2 clusters which bifurcated at a point just greater than $70 \%$ RAPD-based similarity. The type $A$. salmonicida subsp. salmonicida strain (NCIMB 1102) formed a cluster which, with the exception of the French isolates, strains $65-R$ and A450, contained 8 typical strains isolated in North America. The type A. salmonicida subsp. masoucida strain (NCIMB 2020) formed a cluster which, with the exception of strain 028 (isolated from brown trout in the USA) contained 6 typical strains isolated in northern Europe.
Fig. 5 shows the RAPD-based similarity dendrograms prepared for the atypical Aeromonas salmonicida strains. By comparison with the typical strains, genetic heterogeneity among the atypical strains was readily apparent with 23 of 39 atypical strains showing less than $70 \%$ RAPD-based similarity to their closest neighbour. No atypical strain showed a $70 \%$ or greater RAPD-based similarity to any of the 3 type A. salmonicida subspecies strains. The only well-defined cluster contained 4 atypical strains (143/70, MT675, MT373 and MT194) isolated from Atlantic salmon in Scotland.

\section{PFGE analysis}

Initially, 10 atypical Aeromonas salmonicida isolates were screened by PFGE using the enzymes NotI, XhoI, $X b a I$ and Spel to determine which restriction endonu-

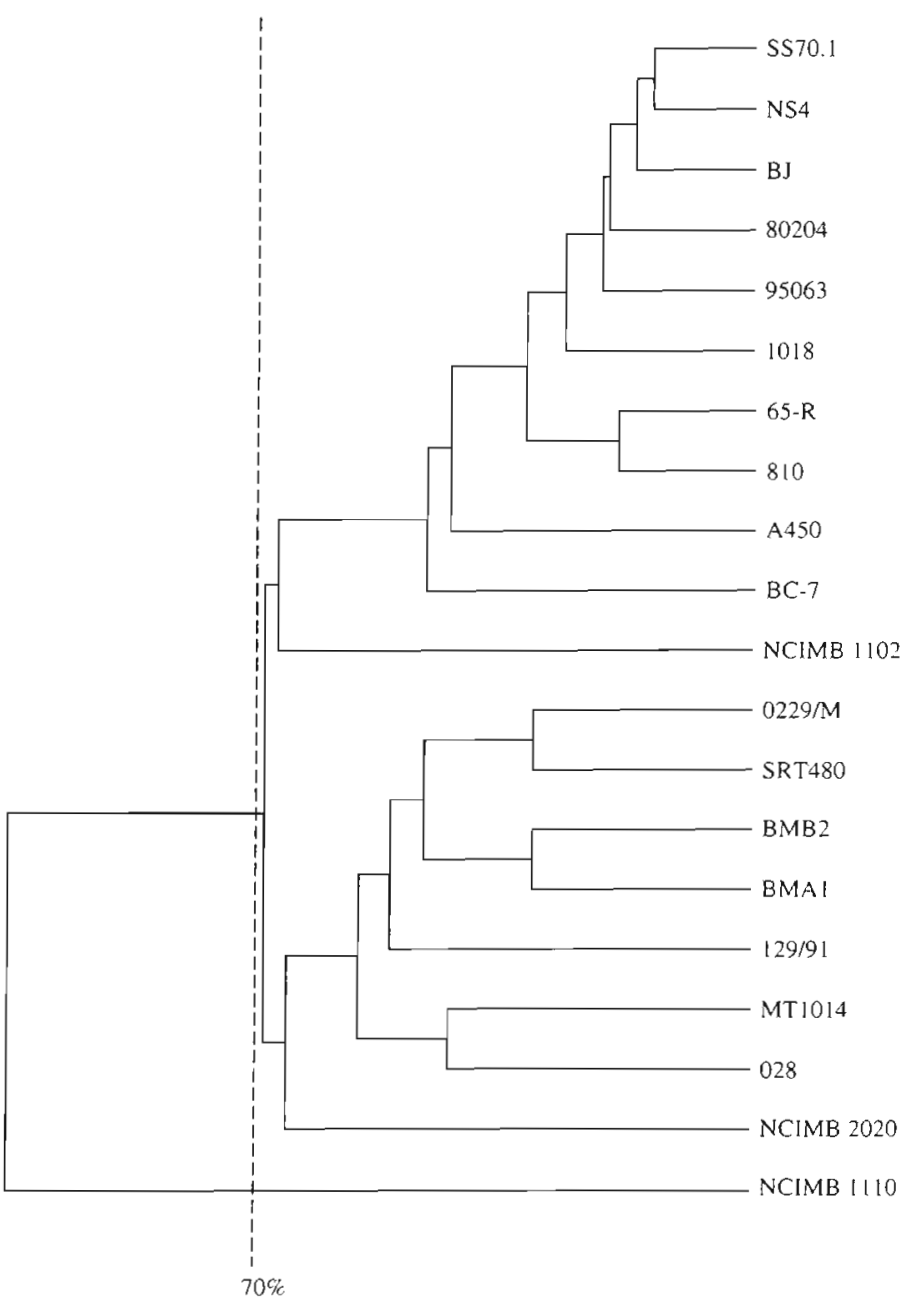

Fig. 4. UPGMA dendrogram describing RAPD-based genetic similarity of typical Aeromonas salmonicida strains. A vertical line denoting a hypothetical node of $70 \%$ RAPD-based similarity is added for comparative analysis 


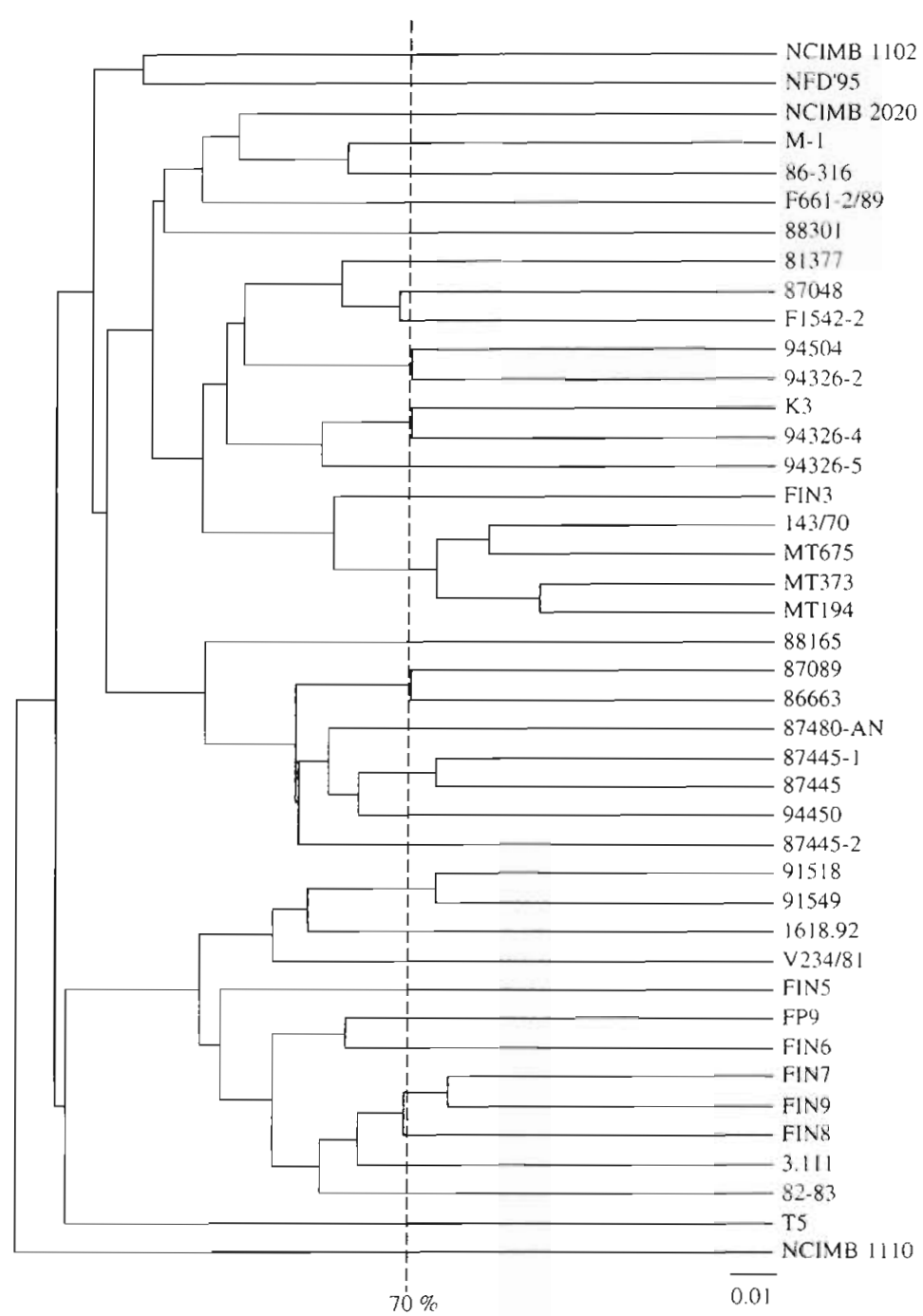

Fig. 5. UPGMA dendrogram describing RAPD-based genetic similarity of atypical Aeromonas salmonicida strains. A vertical line denoting a hypothetical node of $70 \%$ RAPD-based similarity is added for comparative analysis

cleases produced the most informative DNA profiles for strain comparison. NotI and Xhol digestion resulted in greater than 30 DNA fragments of less than $150 \mathrm{~kb}$ in length, $X b a l$ digestion resulted in approximately 40 DNA fragments of between 20 and $250 \mathrm{~kb}$ in length, and Spel digestion resulted in approximately 30 DNA fragments of between 20 and $500 \mathrm{~kb}$ in length. Based on these results, the endonucleases Xbal and SpeI were selected for analysis of genome similarity among the $A$. salmonicida strains. Subsequently, however, restriction endonuclease and PFGE analysis could not be performed on 6 of the atypical strains (strains 94504, K3, 94326-4, T5, 86663 and 94450) as the genomic DNA was severly degraded. Despite repeated attempts, this problem could not be solved and it may be that these particular atypical $A$. salmonicida strains contained sufficient endogenous nucleases to degrade the genomic DNA within the agarose plugs prepared for PFGE.

Fig. 6 shows the PFGE DNA profiles produced for the type and typical Aeromonas salmonicida strains using the restriction endonucleases $X$ baI (Fig. 6A) and Spel (Fig. 6B). In a similar manner to the RAPD analysis, none of the 3 type $A$. salmonicida subspecies strains showed an identical PFGE pattern to one another (Fig. 6A, lanes 2, 3 \& 4) although $A$. salmonicida subsp. masoucida (NCIMB 2020) shared many similar-length PFGE DNA fragments with $A$. salmonicida subsp. salmonicida (NCIMB 1102). The PFGE profiles found among the typical strains were very similar to one another and identical among the majority of strains (Fig. 6A, lanes 5 to 20; and Fig. 6B, lanes 2 to 18 ). This PFGE profile was also clearly similar to that of the type $A$. salmonicida subsp. salmonicida strain (Fig. 6A, lane 2). Fig. 7 shows the PFGE DNA profiles produced for many of the atypical $A$. salmonicida strains using the restriction endonucleases Xbal (Fig. 7A) and Spel (Fig. 7B). Only 2 atypical strains, 87445 and $87445-2$, produced an identical PFGE DNA profile with both $X b a l$ and Spel. Very similar, but not identical, PFGE DNA profiles could be seen among some of the atypiCal strains (Fig. 7A, lanes 7, 8, 9 \& 10 or lanes 11 , $12 \& 13 ;$ Fig. 7B, lanes 7, 8, 9, 10 \& 11 or lanes $12,13 \& 14)$.

Cluster analysis was performed using the PFGE data in a similar manner to the analysis of the RAPD data. However, no analysis was performed on the typical Aeromonas salmonicida strains as there was insufficient variation among the strain profiles, i.e. all the typical strains showed a $90 \%$ or greater similarity to each other. With respect to the atypical strains, only DNA fragments greater than $100 \mathrm{~kb}$ in length were scored in this analysis. Using both Xbal and SpeI restriction endonucleases, 50 DNA fragments were scored for similarity between the atypical $A$. salmonicida strains. Fig. 8 shows the PFGE-based similarity dendrogram prepared for the atypical $A$. salmonicida strains. As with the RAPD analysis, genetic heterogeneity among the atypical strains was readily apparent with 21 of 32 atypical strains showing less than $70 \%$ PFGE-based similarity to their closest neighbour. No atypical strain showed a $70 \%$ or greater PFGEbased similarity to the type $A$. salmonicida subsp. salmonicida (NCIMB 1102) or subsp. achromogenes (NCIMB 1110) strains, while 3 atypical strains from Finland showed a $75 \%$ PFGE-based similarity to the type subsp. masoucida (NCIMB 2020) strain. 


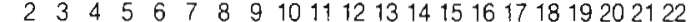
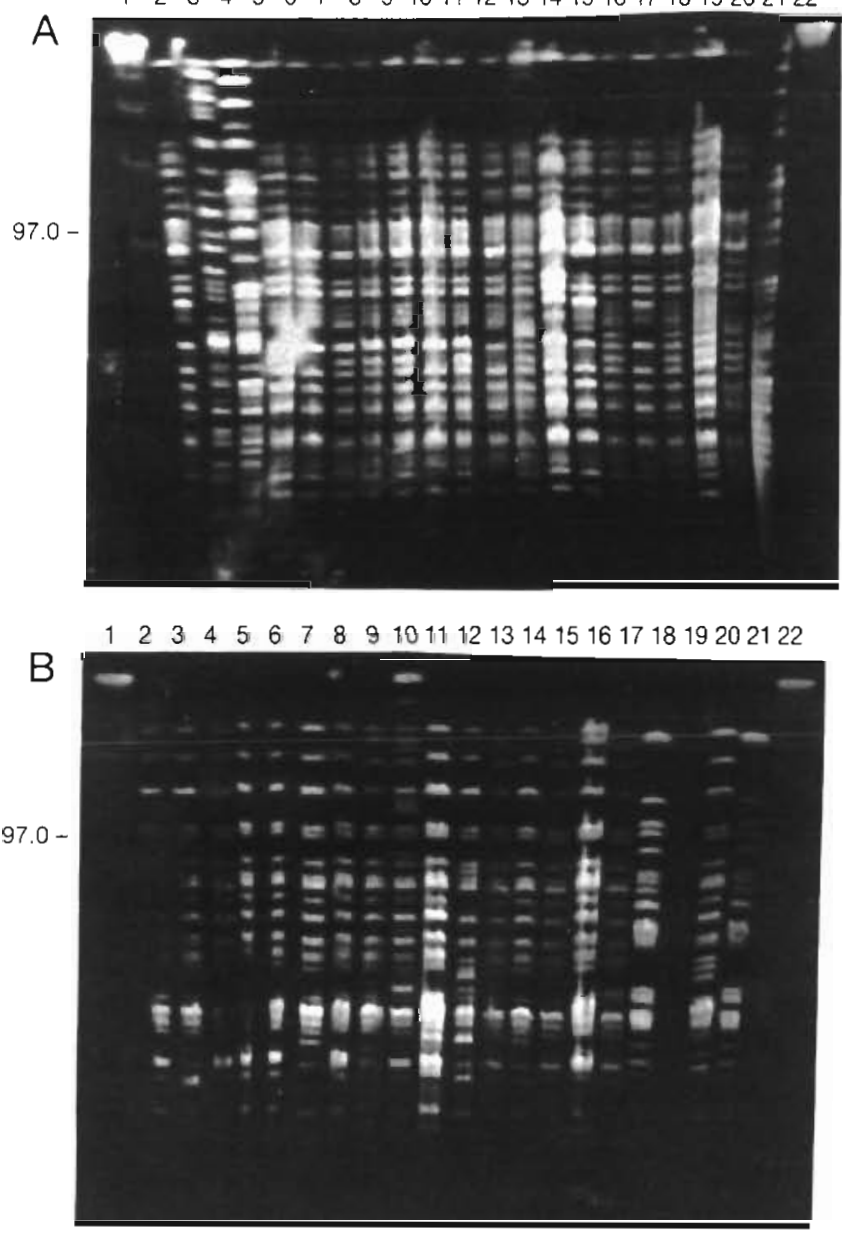

Fig. 6. PFGE profiles of typical Aeromonas salmonicida strains. (A) Xbal digestions, Lanes: 1 \& 22, concatenated phage lambda DNA (48.5 kb) molecular size markers (97 kb marker noted on the left); 2 , NCIMB 1102; 3, NCIMB 1110; 4 , NCIMB 2020; 5, SRT480; 6, 0299/M; 7, BMB2; 8, BMA1; 9 , $129 / 91 ; 10, \mathrm{MT} 1014 ; 11,028 ; 12, \mathrm{BJ} ; 13,1018 ; 14, \mathrm{BC}-7$; 15, 65$R_{i} 16,80204 ; 17, S S 70.1 ; 18,95063 ; 19, N S 4 ; 20,810 ; 21$, A450. (B) Spel digestions, Lanes: 1 \& 22, concatenated phage lambda DNA $(48.5 \mathrm{~kb})$ molecular size markers $197 \mathrm{~kb}$ marker noted on the left); 2 , SRT $480 ; 3,0229 / \mathrm{M} ; 4, \mathrm{BMB} 2 ; 5, \mathrm{BMA} 1 ; 6$, $129 / 91 ; 7$, MT1014; 8, 028; 9, BJ; 10,1018; 11, BC-7; 12, 65-R; 13,$80204 ; 14, \mathrm{SS} 70.1 ; 15,95063 ; 16, \mathrm{NS}_{4} ; 17,810 ; 18, \mathrm{~A} 450 ;$ 19 , blank; $20 \& 21$, non-aeromonad strains

\section{DISCUSSION}

This study describes a genotypic analysis of 17 typical and 39 atypical strains of Aeromonas salmonicida isolated from a variety of host species and geographic locations and also included type strains representing 3 A. salmonicida subspecies. Initially, all the atypical strains were screened with an oligodeoxynucleotide DNA probe designed to specifically recognise members of the species $A$. salmonicida. All the atypical strains reacted positively with this DNA probe reflecting a common genetic relationship between these members of the species A. salmonicida. To further resolve this relationship, the strain collection was examined using the RAPD and PFGE techniques.

DNA profiling using the RAPD technique has been shown to be a very useful method for discriminating among strains of a species (Berg et al. 1994). It has been used successfully to demonstrate genetic heterogeneity among field isolates of Mycoplasma hyopneumoniae
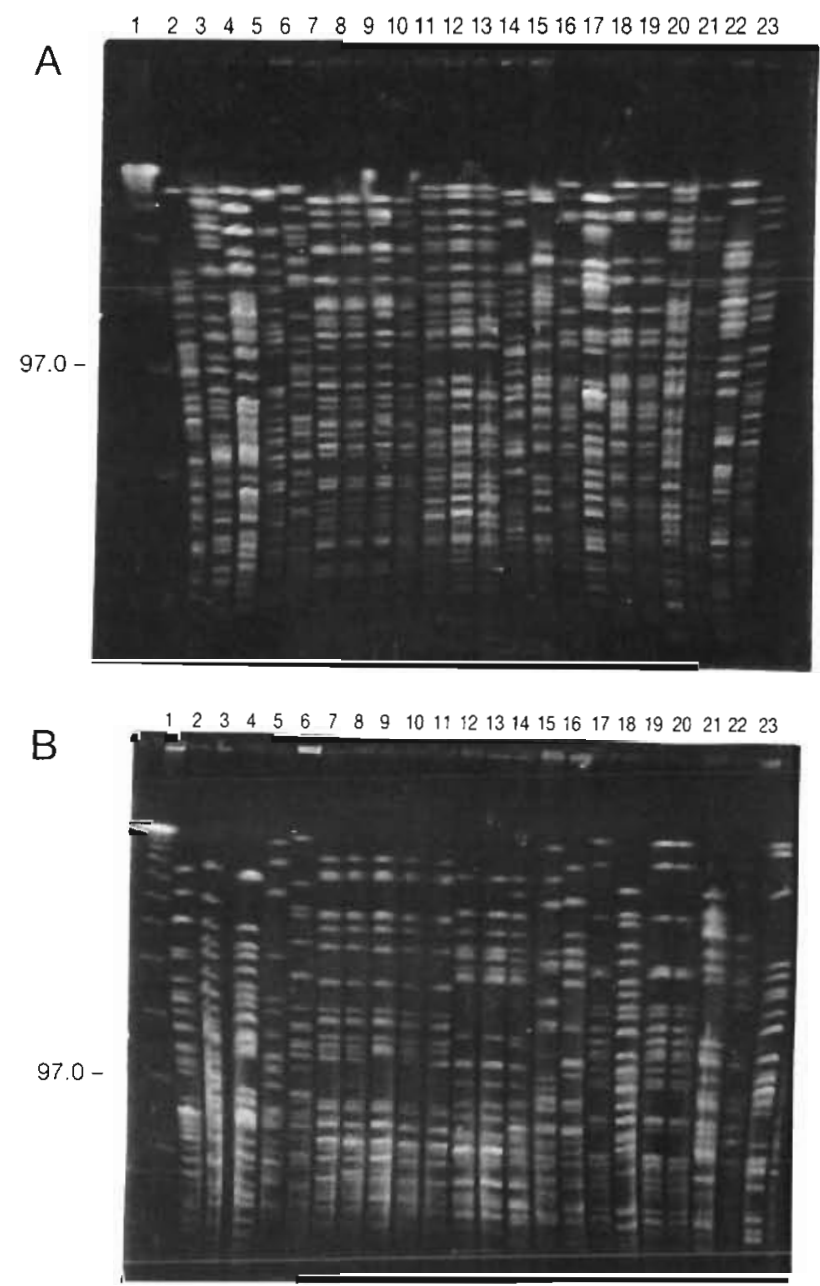

Fig. 7. PFGE profiles of atypical Aeromonas salmonicida strains. (A) XbaI digestions, Lanes: 1, concatenated phage lambda DNA (48.5 kb) molecular size markers (97 kb marker noted on the left); 2 , NCIMB 1102; 3, NCIMB 1110; 4, NCIMB $2020 ; 5,88165 ; 6$, NFD'95; 7,$87089 ; 8,87480-$ an; $^{9} 9,87445-1$; $10,87445-2 ; 11,87445 ; 12,91518 ; 13,91549 ; 14,1618.92 ; 15$ Fin5; 16, FP9; 17, Fin6; 18, Finf; 19, Fin8; 20, Fin9; 21, 3.111; $22,82-83 ; 23, V 234 / 81$. (B) SpeI digestions, Lanes: 1, concatenated phage lambda DNA (48.5 kb) molecular size markers (97 kb marker noted on the left) 2 , NCIMB 1102; 3 , NCIMB $1110 ; 4$, NCIMB $2020 ; 5,88165 ; 6$, NFD'95; 7,$87089 ; 8,87480-$ an; $9,87445-1 ; 10,87445-2 ; 11,91518 ; 12,91549 ; 13,1618.92$; 14. Fin5; 15, FP9; 16, Fin6; 17, Fin7; 18, Fin8; 19, Fin9; $20,3.111 ; 21,82-83 ; 22, \mathrm{~V} 234 / 81 ; 23, \mathrm{~T} 5$ 


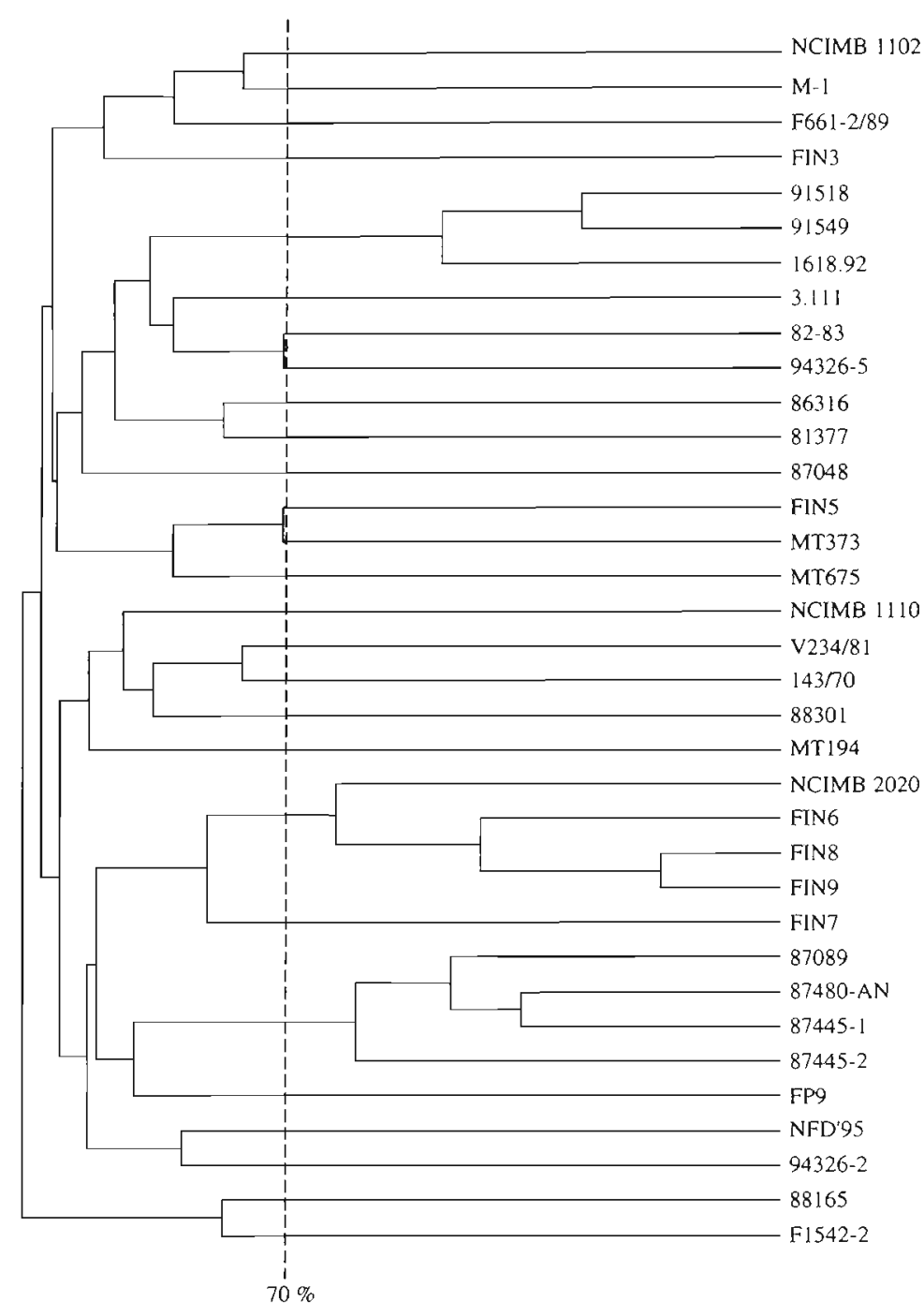

Fig. 8. UPGMA dendrogram describing PFGE-based genetic similarity of the atypical Aeromonas salmonicida strains. A vertical line denoting a hypothetical node of $70 \%$ PFGE-based similarity is added for comparative analysis

(Artiushin \& Minion 1996), to differentiate strains of Salmonella enteritidis (Lin et al. 1996) and to examine reports of clonal lineages of Pseudomonas aeruginosa associated with human disease (Mahenthiralingam et al. 1996). One previous study describing RAPD analysis of 13 typical Aeromonas salmonicida subsp. salmonicida strains isolated from the UK, USA and Japan found identical RAPD profiles among all the typical strains (Miyata et al. 1995). A second RAPD study of typical $A$. salmonicida strains also found very homogeneous patterns with few polymorphic loci (Hanninen et al. 1995). In this study, the use of 3 RAPD primers that amplified 100 DNA fragments for use in strain comparison also showed the close genetic relationship between the typical $A$. salmonicida strains. However, unlike the previous RAPD studies of typical A. salmonicida, it was pos- sible to resolve the strains into 2 clusters within which the majority of the strains correlated with the geographic area of isolation, i.e. one cluster contained predominantly North American strains ( 8 of 10 strains) and the second cluster contained predominantly northern European strains ( 6 of 7 strains). With respect to the atypical $A$. salmonicida strains examined, the RAPD analysis highlighted their genetically heterogeneous nature, with none of the atypical strains showing any close similarity with the type $A$. salmonicida subspecies strains. Within the atypical strains, little clustering of strains correlating with fish host and geographical location were found. The only 2 correlations of note were strains $143 / 70$, MT675, MT373 and MT194, which were all isolated from Atlantic salmon in Scotland, and strains 91518 and 91549, which were isolated from eel in Nova Scotia. The only other eel isolation in the collection, strain 1618-92 from New Brunswick, was placed as their closest neighbour although at less than $70 \%$ RAPDbased similarity.

In a similar fashion to RAPD analysis, PFGE of large genomic DNA fragments has been shown to be a valuable typing method for epidemiological investigations (Lin \& Johnson 1995), including clonal studies (Skov et al. 1995), and has proved to be highly differentiating when other methods were not suitable (Wong et al. 1996). In this study, the PFGE analysis using 2 restriction endonucleases showed the typical Aeromonas salmonicida strains to have greater than $90 \%$ similarity to one another and also to the type $A$. salmonicida subsp. salmonicida strain (NCIMB 1102). This data supported the results found from ICeuI digestion and subsequent PFGE analysis of 9 typical $A$. salmonicida strains reported previously (Umelo \& Trust 1998). With respect to the atypical strains examined, the PFGE analysis also highlighted their genetic heterogeneity. In this case, the noteworthy correlations with strain provenance included the clustering of the 3 Canadian eel isolates, 91518, 91549 and 1618-92, and a cluster of Canadian Atlantic salmon isolates, 87089, 87480-an, 87445-1 and 87445-2.

While both the RAPD and PFGE analyses showed the close genetic similarity of typical strains and Aeromonas salmonicida subsp. salmonicida, and the heterogeneity present among atypical strains, there was little correlation between the 2 methods in identifying clusters of similar atypical strains. Primarily, this is likely due to the small number of strains examined and the large genetic variation detected by both methods 
in this study. Also, discrepancies between strain typing by RAPD and PFGE have been reported for other bacteria (Struelens et al. 1993, Barbier et al. 1996), and may be explained by the fact that these methods explore different types of DNA polymorphisms. PFGE is based on restriction enzyme polymorphisms, while RAPD analyzes sequence polymorphisms of regions complementary to the amplification primers and also length polymorphisms of the regions amplified. Furthermore, it has been reported that plasmids represent approximately $20 \%$ of the $A$. salmonicida genome (Belland \& Trust 1988) although less information is available on the plasmid content of atypical $A$. salmonicida strains. These endogenous plasmids may act as targets for RAPD primers, resulting in the amplification of DNA fragments that would interfere with the similarity analysis. In this analysis, we sought to remove interference by plasmids within the PFGE analysis by analyzing only DNA fragments greater than $100 \mathrm{~kb}$ in length. However, no such limitation could be made on the RAPD analysis. This may explain some of the differences found between the RAPD and PFGE strain clusters, and it shows that molecular typing methods may have some of the disadvantages, including subjectivity, associated with strain characterisation. using phenetic traits. These problems have previously been noted in studies of atypical $A$. salmonicida (Austin et al. 1998). In this study, the RAPD technique produced 100 loci for strain comparison, which was twice the number of scorable loci produced by PFGE. Based on the results, modifications of both the RAPD and PFGE conditions or other genotype methods producing a lower number of comparable loci may be more suitable for the identification of strain clusters of epizootiological significance among the atypical $A$. salmonicida strains. Also, in terms of technique suitability or robustness, problems were experienced with both techniques. Reproducibility of DNA profiles using the RAPD technique proved onerous if different thermocylcers were used, and some of the atypical strains could not be profiled with the PFGE technique.

Finally, in terms of population structure, one previous study using multilocus enzyme electrophoretic analysis differentiated Aeromonas salmonicida into 2 clones (Boyd et al. 1994), one containing typical A. salmonicida strains and the other containing atypical strains. However, the RAPD and PFGE analyses showed that while the typical $A$. salmonicida strains represented a clonal population, the atypical strains examined showed a far greater genetic heterogeneity and cannot be grouped into a clonal population. The data supported the previous suggestion based on DNA:DNA reassociation analysis that the atypical strains encompass sufficient diversity to possibly warrant further subdivision in the future (Belland \& Trust 1988).
Acknowledgements. We are grateful to colleagues for the gifts of strains, and the support of the E.U. AIR Programme (AIR3-CT94-1884) and BioResearch Ireland. B.O'hI, was supported by NUIG and Enterprise Ireland post-graduate fellowships, and is grateful to the European Molecular Biology Organisation (EMBO), and J. L. Larsen, M. N. Skov and K. Pedersen of the Royal Veterinary and Agricultural University, Frederiksberg, Denmark, for their help with PFGE.

\section{LITERATURE CITED}

Artiushin S, Minion FC (1996) Arbitrarily primed PCR analysis of Mycoplasma hyopneumoniae field isolates demonstrates genetic heterogeniety. Int $\mathrm{J}$ Syst Bacteriol 46 : $324-328$

Austin B, Austin DA (1993) Aeromonadaceae representatives (Aeromonas salmonicida). In: Austin B, Austin DA (eds) Bacterial fish pathogens; disease in farmed and wild fish, 2nd edn. Ellis Horwood Ltd, Chichester, p 86-170

Austin B, Austin DA, Dalsgaard I, Gudmundsdottir BK, Hoie S, Thornton JM, Larsen JL, O'hlci B, Powell R (1998) Characterisation of atypical Aeromonas salmonicida by different methods. Syst Appl Microbiol 21:50-64

Austin DA, McIntosh D, Austin B (1989) Taxonomy of fish associated Aeromonas spp., with the description of Aeromonas salmonicida subsp. smithia subsp. nov. Syst Appl Microbiol 11:277-290

Ausubel FM, Brent R, Kingston RE, Moore DD, Seidman JG, Smith JA, Struhl K (1992) Short protocols in molecular biology, 2nd edn. John Wiley \& Sons, New York

Barbier N, Saulnier P, Chachaty E, Dumontier S, Andremont A (1996) Random amplified polymorphic DNA typing versus pulsed-field gel electrophoresis for epidemiological typing of vancomycin-resistant enterococci. J Clin Microbiol 34:1096-1099

Belland RJ, Trust TJ (1988) DNA:DNA reassociation analysis of Aeromonas salmonicida. J Gen Microbiol. 134:307-315

Berg DE, Akopyants NS, Kersulyte D (1994) Fingerprinting microbial genomes using the RAPD or AP-PCR method. Meth Mol Cell Biol 5:13-24

Bootsma R, Fijan N, Blommaert J (1977) Isolation and preliminary identification of the causative agent of carp erythrodermatitis. Vet Arch 47:291-302

Boyd EF, Hiney MP, Peden JF, Smith PR (1994) Assessment of genetic diversity among Aeromonas salmonicida isolates by multi enzyme electrophoresis. J Fish Dis 17:97-98

Caetano-Anolles G, Bassam BJ, Gresshoff PM (1991) DNA amplification fingerprinting using very short arbitrary oligonucleotide primers. Biotechnology 9:553-557

Cameron DN, Khambaty FM, Wachsmuth IK, Tauxe RV, Barret TJ (1994) Molecular characterization of Vibrio cholera 01 strains by pulsed-field gel electrophoresis. J Clin Microbiol 32:1685-1690

Cornick JW, Morrison CM, Zwicker B, Shum G (1994) Atypical Aeromonas salmonicida infection in Atlantic cod, Gadus morhua. J Fish Dis 7:495-499

Dalsgaard I, Paulsen H (1986) Atypical Aeromonas salmonicida isolated from diseased sand-eels. Ammodytes lancea (Cuvier) and Hyperoplus lanceolatus (Lesauvage). J Fish Dis 9:361-364

Elliott DG, Shotts EB (1980) Aetiology of an ulcerative disease in goldfish Carassius auratus (L.): microbiological examination of diseased fish from seven locations. J Fish Dis 3: $133-143$

Evelyn TPT (1971) An aberrant strain of the fish pathogen Aeromonas salmonicida isolated from a marine host, the 
sablefish (Anoplopoma fimbria), and from two species of cultured Pacific salmon. J Fish Res Board Can 28 $1629-1634$

Felsenstein J (1993) PHYLIP: phylogeny inferance package Distributed by author, University of Washington, Seattle

Gustafson CE, Thomas CJ, Trust TJ (1992) Detection of Aeromonas salmonicida from fish by using polymerase chain reaction amplification of the virulence surface array protein gene. Appl Environ Microbiol 58:3816-3825

Hanninen ML, Ridell J, Hirvela-Koski V (1995) Phenotypic and molecular characteristics of Aeromonas salmonicida subsp. salmonicida isolated in Southern and Northern Finland. J Appl Bacteriol 79:12-21

Hastein T, Saltveit SJ, Roberts RJ (1978) Mass mortality among minnows Phoxinus phoxinus (L.) in Lake Tveitevatn, Norway, due to an aberrant strain of Aeromonas salmonicida. J Fish Dis 1:241-249

Hiney M, Dawson MT, Heery DM, Smith PR, Gannon F, Powell R (1992) DNA probe for Aeromonas salmoncida. Appl Environ Microbiol 58:1039-1042

Kimura T (1969) A new subspecies of Aeromonas salmonicida as an etiological agent of furunculosis on 'Sakuramasu' (Oncorhynchus masou) and pink salmon (O. gorbuscha) rearing for maturity. Part 2. On the morphological and physiological properties. Fish Pathol 3:45-52

Kitao T, Yoshida T, Aoki T, Fukudome M (1985) Characterization of an atypical Aeromonas salmonicida strain causing epizootic ulcer disease in cultured eel. Fish Pathol 29: $107-114$

Lane DJ (1991) 16S/23S rRNA sequencing. In: Stackebrandt E, Goodfellow M (eds) Nucleic acid techniques in bacterial systematics. John Wiley \& Sons, New York, p 115-175

Lin AW, Usera MA, Barrett TJ, Goldsby RA. (1996) Application of random amplified polymorphic DNA analysis to differentiate strains of Salmonella enteritidis. J Clin Microbiol 34:870-876

Lin WJ, Johnson EA (1995) Genome analysis of Clostridium botulinum type A by pulsed-field gel electrophoresis. Appl Environ Microbiol 61:4441-4447

Mahenthiralingam E, Campbell ME, Foster J, Lam JS, Speert DP (1996) Random amplified polymorphic DNA typing of Pseudomonas aeruginosa isolates recovered from patients with cystic fibrosis. J Clin Microbiol. 34:1129-1135

Martinez-Murcia A.J, Benlloch S, Collins MD (1992) Phylogenetic interrelationships of members of the genera Aeromonas and Plesiomonas as determined by $16 \mathrm{~S}$ ribosomal DNA sequencing: lack of congruence with results of DNADNA hybridisations. Int J Syst Bacteriol 42:412-421

McCormick WA, Stevenson RMW, MacInnes JI (1990) Restriction endonuclease fingerprinting analysis of Canadian isolates of Aeromonas salmonicida. Can J Microbiol 36:24-32

Miyata $M$, Aoki $\Upsilon$, Inglis V, Yoshida T, Endo M (1995) RAPD analysis of Aeromonas salmonicida and Aeromonas hydrophila. J Appl Bacteriol 79:181-185

Morgan UM, Constantine CC, Greene WK, Thompson RCA (1993) RAPD (random amplified polymorphic DNA) analysis of Giardia DNA and correlation with isoenzyme data. Trans R Soc Trop Med 87:702-705

Nielsen B, Olsen JE, Larsen JL (1993) Plasmid profiling as an epidemiological marker within Aeromonas salmonicida. Dis Aquat Org 15:129-135
Nielsen B, Olsen JE, Larsen JL (1994) Ribotyping of Aeromonas salmonicida subsp. salmonicida. Dis Aquat Org 18 : $155-158$

Paterson WD, Douey D, Desautels D (1980) Isolation and identification of an atypical Aeromonas salmonicida strain causing epizootic losses among Atlantic salmon (Salmo salar) reared in a Nova Scotian hatchery. Can J Fish Aquat Sci 37:2236-2241

Pedersen K, Kofod H, Dalsgaard I, Larsen JL (1994) Isolation of oxidase-negative Aeromonas salmonicida from diseased turbot Scophthalmus maximus. Dis Aquat Org 18:149-154

Popoff M (1984) Genus III. Aeromonas Kluyver and Van Niel 1936, 398 $\mathrm{AL}$. In: Kreig NR, Holt JG (eds) Bergey's manual of systematic bacteriology, Vol 1 Williams \& Wilkins Co, Baltimore, p 545-548

Schwartz DC, Cantor CP (1984) Separation of yeast chromosome-sized DNAs by pulsed-field gradient gel electrophoresis. Cell 37:67-75

Skov MN, Pedersen K, Larsen JL (1995) Comparison of pulsed-field gel electrophoresis, ribotyping, and plasmid profiling for typing of Vibrio anguillarum serovar O1. Appl Environ Microbiol 61:1540-1545

Smith IW (1963) The classification of Bacterium salmonicida. J Gen Microbiol 33:263-274

Struelens M, Carlier E, Maes N, Serruys E, Quint WGV, Van Belkum A (1993) Nosocomial colonization and infection with multiresistant Acinetobacter baumannii: outbreak delineation using DNA macrorestriction analysis and PCR-fingerprinting. J Hosp Infect 25:15-32

Thornton JM, Austin DA, Austin B, Powell R (1999) Small subunit rRNA gene sequences of Aeromonas salmonicida subsp. smithia and Haemophilus piscium reveal pronounced similarities with $A$. salmonicida subsp. salmonicida. Dis Aquat Org 35:155-158

Umelo E, Trust TJ (1998) Physical map of the chromosome of Aeromonas salmonicida and genomic comparisons between Aeromonas strains. Microbiology 144:2141-2149

Whittington RJ, Gudkovs N, Carrigan MJ, Ashburn LD, Thursten SJ (1987) Clinical microbiological and epidemiological findings in recent outbreaks of goldfish ulcer disease due to atypical Aeromonas salmonicida in southeastern Australia. J Fish Dis 10:353-362

Wiklund T (1990) Atypical Aeromonas salmonicida isolated from ulcers of pike, Esox lucius L. J Fish Dis 13:541-544

Wiklund T, Bylund G (1991) A cytochrome oxidase negative bacterium (presumptively an atypical Aeromonas salmonicida) isolated from ulcerated flounders (Platichthys flesus L.) in the northern Baltic sea. Bull Eur Assoc Fish Pathol 11:74-76

Wiklund T, Bylund G (1993) Skin ulcer disease of flounder Platichthys flesus in the northern Baltic sea. Dis Aquat Org 11:165-174

Wiklund T, Dalsgaard I (1998) Occurrence and significance of atypical Aeromonas salmonicida in non-salmonid and salmonid fish species: a review. Dis Aquat Org 32:49-69

Wiklund T, Dalsgaard I, Eerola E, Olivier G (1994) Characteristics of 'atypical', cytochrome oxidase-negative Aeromonas salmonicida isolated from ulcerated flounders (Platichthys flesus L.). J Appl Bacteriol 76:511-520

Wong HC, Lu KT, Pan TM, Lee CL, Shih DYC (1996) Subspecies typing of Vibrio parahaemolyticus by pulsed-field gel electrophoresis. J Clin Microbiol 34:1535-1539

Submitted: June 13, 1999; Accepted: November 21, 1999

Proofs received from author(s): January 6, 2000
Editorial responsibility: Larry Vaughan,

Portsmouth, New Hampshire, USA 